\title{
IL-22 protects against liver pathology and lethality of an experimental blood-stage malaria infection
}

\section{Béatris Mastelic ${ }^{1+}{ }^{+}$Ana Paula Freitas do Rosario ${ }^{1}$, Marc Veldhoen $^{2 \dagger}$, Jean Christophe Renauld ${ }^{3}$, William Jarra ${ }^{1}$, Anne-Marit Sponaas ${ }^{1}$, Sophie Roetynck ${ }^{1}$, Brigitta Stockinger ${ }^{2}$ and Jean Langhorne ${ }^{1}{ }^{*}$}

\author{
1 Divisions of Parasitology, MRC National Institute for Medical Research, London, UK \\ 2 Divisions of Molecular Immunology, MRC National Institute for Medical Research, London, UK \\ ${ }^{3}$ Ludwig Institute for Cancer Research, Brussels, Belgium
}

Edited by:

Pierre Miossec, University of Lyon, France

\section{Reviewed by:}

Takayuki Yoshimoto, Tokyo Medical University, Japan

Urszula Krzych, Walter Reed Army Institute of Research, USA

\section{*Correspondence.}

Jean Langhorne, Division of Parasitology, MRC National Institute for Medical Research, The Ridgeway, London NW7 1AA, UK.

e-mail: jlangho@nimr.mrc.ac.uk

\section{${ }^{+}$Present address:}

Béatris Mastelic, Departments of Pathology and Immunology, World Health Organization Collaborating Center for Vaccinology and Neonatal Immunology, University of Geneva, Geneva, Switzerland;

Marc Veldhoen, Laboratory of Lymphocyte Signalling and

Development, The Babraham Institute, Cambridge, UK.
The host response following malaria infection depends on a fine balance between levels of pro-inflammatory and anti-inflammatory mediators resulting in the resolution of the infection or immune-mediated pathology. Whilst other components of the innate immune system contribute to the pro-inflammatory milieu, T cells play a major role. For blood-stage malaria, $\mathrm{CD}^{+}{ }^{+}$and $\gamma \delta \mathrm{T}$ cells are major producers of the IFN- $\gamma$ that controls parasitemia, however, a role for TH17 cells secreting IL-17A and other cytokines, including IL-17F and IL-22 has not yet been investigated in malaria. TH17 cells have been shown to play a role in some protozoan infections, but they also are a source of pro-inflammatory cytokines known to be involved in protection or pathogenicity of infections. In the present study, we have investigated whether IL-17A and IL-22 are induced during a Plasmodium chabaudi infection in mice, and whether these cytokines contribute to either protection or to pathology induced during the infection. Although small numbers of IL-17- and IL-22-producing CD4 T cells are induced in the spleens of infected mice, a more pronounced induction is observed in the liver, where increases in mRNA for IL-17A and, to a lesser extent, IL-22 were observed and $\mathrm{CD}^{+} \mathrm{T}$ cells, rather than CD4 T cells, are a major source of these cytokines in this organ. Although the lack of IL-17 did not affect the outcome of infection or pathology, lack of IL-22 resulted in 50\% mortality within 12 days after infection with significantly greater weight loss at the peak of infection and significant increase in alanine transaminase in the plasma in the acute infection. As parasitemias and temperature were similar in IL-22 KO and wild-type control mice, our observations support the idea that IL-22 but not IL-17 provides protection from the potentially lethal effects of liver damage during a primary $P$. chabaudi infection.

Keywords: TH17, IL-17, IL-22, malaria, Plasmodium chabaudi, liver damage

\section{INTRODUCTION}

The outcome of infection with the malaria parasite is determined by factors affecting the tight balance in the kinetics and magnitude of pro-inflammatory and anti-inflammatory cytokine produced by the innate and acquired immune response (Langhorne et al., 2008). In Plasmodium (P.) chabaudi infections in mice, $\mathrm{T}_{\mathrm{H}} 1 \mathrm{CD} 4^{+}$ $\mathrm{T}$ cells play a dual role: mediating protective immunity, together with B cells during blood-stage infection (Meding and Langhorne, 1991), and contributing to severe inflammation and pathogenesis through the production of IFN- $\gamma$ (Li et al., 2003). However, since the identification of $\mathrm{T}_{\mathrm{H}} 17$ cells (Mangan et al., 2006; Veldhoen et al., 2006) and the discovery of the plasticity of $\mathrm{T}$ cell cytokine responses (Zhou et al., 2009; O'Shea and Paul, 2010), the $\mathrm{T}_{\mathrm{H}} 1 / \mathrm{T}_{\mathrm{H}} 2$ paradigm in infections has been revisited, and protection or immunopathology has also been attributed to other cells types such as $T_{H} 17$ cells in some infection models (Awasthi and

Abbreviations: AHR, aryl hydrocarbon receptor; ALT, alanine transaminase; IMDM, Iscove's medium; i.p., intraperitoneally; iRBC, infected red blood cells; KO, knockout; P., Plasmodium; qRT-PCR, quantitative real-time PCR; WT, wild-type.
Kuchroo, 2009). Although the involvement of pro-inflammatory cytokines derived from $\mathrm{CD}^{+} \mathrm{T}_{\mathrm{H}} 1$ cells in either immunopathology or immunity to malaria has been extensively investigated, any role of the cytokines IL-17 and IL-22 produced by $\mathrm{T}_{\mathrm{H}} 17$ cells or other cells remains undetermined in $P$. chabaudi infections. In addition, since $\mathrm{T}_{\mathrm{H}} 17$ cells themselves have a considerable plasticity, they could also be a potential source of IFN- $\gamma$ (Kurschus et al., 2010), which hitherto was thought to be produced mainly by $\mathrm{CD} 4^{+} \mathrm{T}_{\mathrm{H}} 1$ cells in malaria infections.

$\mathrm{T}_{\mathrm{H}} 17$ cells are identified and distinguished by their ability to secrete IL-17A and other cytokines, including IL-17F and IL22. They can coordinate local tissue inflammation through the up-regulation of pro-inflammatory cytokines and chemokines including IL-6, IL-8, G-CSF, and MCP-1, recruiting neutrophils and activating T cells (Aggarwal et al., 2003; Moseley et al., 2003). Moreover, $\mathrm{T}_{\mathrm{H}} 17$ cells were shown to have the ability to produce both IFN- $\gamma$ and IL-17, or, in vitro, to shut off IL-17 production (Annunziato et al., 2007; Bending et al., 2009; Lee et al., 2009; Hirota et al., 2011). Although IL-17A was shown at first to play a major role in the pathogenesis of various autoimmune diseases in 
mouse models (Langrish et al., 2005; Ivanov et al., 2006; Komiyama et al., 2006; Steinman, 2007) induction of $\mathrm{T}_{\mathrm{H}} 17$ cells has also been described in infections of Toxoplasma gondii (Kelly et al., 2005) and Leishmania (Pitta et al., 2009), suggesting that they may play a role in protection or immunopathology of parasitic diseases.

IL-22 is regulated by IL-23, differently from IL-17, and can be co-expressed with IL-17A in $\mathrm{T}_{\mathrm{H}} 17$ cells (Liang et al., 2006; Zheng et al., 2007). Its production by $\mathrm{T}_{\mathrm{H}} 17$ cells is dependent on Notch signaling and the stimulation of the aryl hydrocarbon receptor (AHR; Veldhoen et al., 2008; Alam et al., 2010). In fact, the induction of c-Maf, downstream of TFG- $\beta$, has been demonstrated as inducing suppression of IL-22 production in $\mathrm{T}_{\mathrm{H}} 17$ cells (Rutz et al., 2011). IL-22 is also produced by NKT cells (Goto et al., 2009), $\mathrm{T}_{\mathrm{H}} 1$, innate lymphoid cells (Taube et al., 2011), and NK cells (Ren et al., 2011). IL-22 production is increased during chronic inflammatory diseases. For example, it has been linked to tuberculosis (Matthews et al., 2011), and dermal inflammation such as psoriasis, where it induces production of antimicrobial proteins needed for the defense against pathogens in the skin (Wolk et al., 2004; Sonnenberg et al., 2011) and gut (Aujla et al., 2008). IL22 also plays a protective role in hepatitis (Radaeva et al., 2004; Xu et al., 2011; Zhang et al., 2011). Therefore, depending on the tissues, $\mathrm{T}_{\mathrm{H}}$ 17-derived IL-22 might either enhance inflammation or limit the tissue damage induced by IL-17A (Wolk and Sabat, 2006; Zenewicz et al., 2007). There have been very few studies investigating IL-17 or IL-22 in malaria, although one study in West Africa identified polymorphisms in the IL-22 gene which are associated with resistance and susceptibility (Koch et al., 2005) suggesting a potential involvement of IL-22, and a second study in macaque malaria/AIDS-virus co-infection model, has demonstrated a protective role for IL-17 and IL-22, via $\mathrm{T}_{\mathrm{H}} 1$ response inhibition (Ryan-Payseur et al., 2011). In the present study we have investigated whether IL-17A and/or IL-22 are induced during a $P$. chabaudi infection in mice, and whether these cytokines contribute to either protection or to pathology induced during the infection. We show that IL-22 but not IL-17 provides protection from fatal liver tissue damage during a primary P. chabaudi infection.

\section{MATERIALS AND METHODS MICE, PARASITES, AND INFECTION}

All experimental animals were kept in pathogen-free animal facilities at the MRC National Institute for Medical Research (NIMR, London, UK) in accordance with local guidelines. Male and female C57BL/6 mice, Il17 $\mathrm{a}^{\mathrm{Cre}+/+} \mathrm{R} 26 \mathrm{R}^{\mathrm{eYFP}}$ mice and Ill7a $\mathrm{a}^{\mathrm{Cre}+/-} \mathrm{R}_{26 \mathrm{R}^{\mathrm{eYFP}}}$ mice (Hirota et al., 2011), ill7A ${ }^{-/-}$mice, kindly provided by Dr. A. Smith (Schmidt and Bradfield, 1996), and $i l 22^{-1-}$ mice (Kreymborg et al., 2007). All knockout (KO) mice were bred in the NIMR specific pathogen-free unit on the C57BL/6 background and the genotype of each of the mice was always verified before use. All mice were used at 6-8 weeks of age.

The Il17 $\mathrm{a}^{\mathrm{Cre}+/+} \mathrm{R} 26 \mathrm{R}^{\text {eYFP }}$ mice and Il17a $\mathrm{Cre+/-}$ R26R ${ }^{\text {eYFP }}$ mice allow permanent tracing of cells with activation of the locus encoding the signature cytokine IL-17A. Briefly, the Cre recombinase activity is visualized by eYFP expression from the Rosa26 promoter. Therefore, eYFP is expressed in all cells that had activated IL-17A and their progeny, thus allowing the identification of cells that have switched on the IL-17 program as well as alternative effector programs that might have been activated. In the $1117 \mathrm{a}^{\mathrm{Cre}+/+} \mathrm{R} 26 \mathrm{R}^{\mathrm{eYFP}}$ mice (Cre/Cre homozygous), the IL-17A gene is replaced by the Cre recombinase, whereas in $\mathrm{Il} 17 \mathrm{a}^{\mathrm{Cre}+1-} \mathrm{R} 26 \mathrm{R}^{\text {eYFP }}$ mice (Cre \pm heterozygous), IL-17A is not replaced by the Cre recombinase, allowing tracking of IL-17 $\mathrm{A}^{\mathrm{eYFP}+}$ expression in vivo.

Mice were infected with $1 \times 10^{5} \mathrm{P}$. chabaudi (AS) infected red blood cells (iRBC) and parasitemia, weight loss, and body temperature were monitored as previously described (Li et al., 2003). All animal experiments were conducted under a British Home Office license and according to international guidelines and UK Home Office regulations, after approval from the NIMR Ethical Review Panel.

\section{CELL LINES AND PEPTIDES}

Monoclonal antibodies specific for IL-17A [Uyttenhove and Van Snick, 2006; clone MM17F3, mouse Immunoglobulin G (IgG) 1] and IL-22 (Ma et al., 2008; Dumoutier et al., 2009; AM 22.1, mouse IgG2a) were used for in vivo neutralization and for flow cytometry. The hybridomas were cultured in Iscove's medium (IMDM, Sigma, UK) with $5 \%$ fetal calf serum (FCS), $1 \mathrm{mM} \mathrm{L-Glutamine,}$ $10 \mathrm{mM}$ Hepes, $5 \times 10^{-5} \mathrm{M} \beta$-Mercaptoethanol, $100 \mu \mathrm{g} / \mathrm{ml}$ penicillin, $100 \mathrm{U} / \mathrm{ml}$ streptomycin, and $1 \mathrm{mM}$ Sodium pyruvate (complete IMDM), and purified from in vitro cultures by Protein A (Bio-Rad) affinity chromatography (Endotoxin $<10 \mathrm{IU}$ ). $0.5 \mathrm{mg} /$ mouse of neutralizing antibody was given intraperitoneally (i.p.), twice weekly or every other day for anti-IL-17A and anti-IL-22 treatment, respectively.

\section{ANTIBODIES AND FLOW CYTOMETRIC ANALYSIS}

Spleen cells from naïve or P. chabaudi-infected mice were mashed through a $70-\mu \mathrm{m}$ sieve (Falcon) into complete IMDM to create a single-cell suspension. Erythrocytes were lysed with red blood cell lysis buffer (Sigma), and the cell pellet was washed and resuspended in FACS buffer [1\% (wt/vol) bovine serum albumin, $5 \mathrm{mM}$ EDTA, and $0.01 \%$ sodium azide in PBS]. Mononuclear liver cells were isolated as described in Tupin and Kronenberg (2006). Briefly, the liver is perfused with PBS to remove external blood and placed into $5 \mathrm{ml} \mathrm{IMDM}+2 \% \mathrm{FCS}+10 \mathrm{mM}$ HEPES. The whole liver is mashed through a $70-\mu \mathrm{m}$ filter to give a single-cell suspension, and centrifuged at RT for $7 \mathrm{~min}$ at $500 \mathrm{~g}$. The cell pellet is washed with $10 \mathrm{ml} \mathrm{IMDM}+2 \%$ FCS $+10 \mathrm{mM}$ HEPES and centrifuged as before. The cell pellet is resuspended in $25 \mathrm{ml}$ of $37.5 \%$ Percoll $+100 \mathrm{U} / \mathrm{ml}$ Heparin in IMDM (at RT), and centrifuged at RT for $12 \mathrm{~min}$ at $700 \mathrm{~g}$ with no brake. The mononuclear cells form a tight pellet at the base of the tube. The supernatant is removed and the cell pellet resuspended in IMDM, and centrifuged at $4^{\circ} \mathrm{C}$ for $5 \mathrm{~min}$ at $300 \mathrm{~g}$.

Antibodies used were CD8 $\alpha$ Biotin, CD4 Pacific Blue, TCR $\gamma \delta$ PE, NK1.1 PE, IL-17A Alexa Fluor 647, and IFN- $\gamma$ FITC (eBiosciences, Insight Biotechnology, London, UK). IL-22 was detected using the polyclonal PE anti-mouse IL-22 antibody (BioLegend). Isotype controls were included in each staining. Before addition of specific fluorescently labeled antibodies, $2 \times 10^{6}$ cells were preincubated at room temperature for $10 \mathrm{~min}$ with anti-Fc receptor antibody (Unkeless, 1979) to prevent non-specific binding via the 
FcR. All other preparations with antibodies for extracellular staining were incubated for $20 \mathrm{~min}$ on ice. For intracellular staining, cells were stimulated with $50 \mathrm{ng} / \mathrm{ml}$ PMA (Sigma), $500 \mathrm{ng} / \mathrm{ml}$ Ionomycin (Sigma) for $2 \mathrm{~h}$ at $37^{\circ} \mathrm{C}, 7 \% \mathrm{CO}_{2}$. Ten micrograms per milliliter Brefeldin A (Sigma) was added for the last $2 \mathrm{~h}$ of culture. In Figure 3, cells were restimulated with $500 \mathrm{ng} / \mathrm{ml}$ Phorbol dibutyrate $(\mathrm{PdBU})$ and $500 \mathrm{ng} / \mathrm{ml}$ ionomycin in the presence of $1 \mu \mathrm{g} / \mathrm{ml}$ Brefeldin A (Sigma) for $2 \mathrm{~h}$. Cells were then fixed with $3.65 \%$ formaldehyde solution from Sigma and permeabilized with $0.1 \%$ NP40 before intracellular staining. Data were acquired on a CyAn ADP analyzer (Beckman Coulter Cyan ADP) using Summit software, and the proportions of cells were determined using FlowJo software (Treestar).

\section{RNA EXTRACTION AND cDNA SYNTHESIS}

Total RNA was extracted from $5 \times 10^{6}$ cells splenocytes or mononuclear cells from liver from uninfected and $P$. chabaudiinfected mice. Cells were resuspended in TRIzol reagent (Life Technologies), according to the manufacturer's instructions, after which $5 \mu \mathrm{g}$ of total RNA were reverse transcribed using Superscript II RT (Life Technologies) at $42^{\circ} \mathrm{C}$ for $50 \mathrm{~min}, 70^{\circ} \mathrm{C} 15 \mathrm{~min}$,

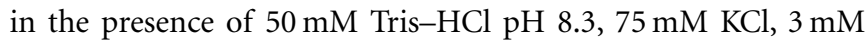
$\mathrm{MgCl}_{2}, 5 \mathrm{mM}$ DTT (Dithiothreitol), $0.5 \mathrm{mM}$ dNTPs, $8 \mathrm{U}$ RNasin, and $5 \mu \mathrm{M}$ Oligo $(\mathrm{dT})_{16}$. The cDNA was finally treated with $2.5 \mathrm{U}$ RNAse $\mathrm{H}$ at $37^{\circ} \mathrm{C}$ for $20 \mathrm{~min}$ to remove any RNA residues.

\section{QUANTITATIVE REAL-TIME PCR}

Real-time quantitative PCR reactions were performed using SYBR Green PCR Core Reagents (ABgene). PCR amplifications were performed in duplicate wells in a total volume of $25 \mu \mathrm{l}$, containing $1 \mu \mathrm{l} \mathrm{cDNA}$ sample, $2 \mu \mathrm{M}$ of each primer, $12.5 \mathrm{ml}$ of Absolute QPCR SYBR green mix, according to the manufacturer's instructions. The resultant PCR products were measured and elaborated using an Applied Biosystems GenApm 7000 Sequence detection system (ABI Prism 7000; primers sequences, Table A1 in Appendix).

The PCR cycling protocol entailed 1 cycle at $50^{\circ} \mathrm{C}$ for $2 \mathrm{~min}$ and then $95^{\circ} \mathrm{C}$ for $15 \mathrm{~min}$, to activate the DNA polymerase, followed by 40 cycles each consisting of $95^{\circ} \mathrm{C}$ for $15 \mathrm{~s}$ and $1 \mathrm{~min}$ at $60^{\circ} \mathrm{C}$.

Analysis of the relative changes (arbitrary units) in gene expression required calculations based on the cycle threshold (CT) following the $2^{-\Delta \Delta C T}$ method (Pfaffl, 2001). $\Delta \Delta \mathrm{CT}$ was calculated as the difference between the $\Delta \mathrm{CT}$ values of the samples and the $\Delta \mathrm{CT}$ values of a calibrator sample; $2^{-\Delta \Delta \mathrm{CT}}$ was the relative mRNA unit representing the fold induction over control.

All quantifications were normalized to the level of Ubiquitin gene expression (housekeeping gene). Test samples were expressed as the fold increase of gene expression compared with expression in normal uninfected mice (mean of expression from three uninfected mice).

\section{PLASMA CYTOKINE MEASUREMENTS}

Cytokine production was measured in the supernatant with a bead-based (Multiplex) cytokine detection assay (eBioscience, UK). The samples were processed using the manufacturers protocol and acquired on FACS Calibur and analyzed using FlowCytomix ${ }^{\mathrm{TM}}$ Pro 2.4 software (eBiosciences).

\section{ALANINE TRANSAMINASE QUANTITATION IN PLASMA}

Mouse blood samples were collected and centrifuged for collection of plasma. Plasma samples from naïve and infected samples were diluted 1:10 or 1:100, respectively in PBS. Levels of alanine transaminases (ALT) in serum were quantified using a Cobas C111 chemistry analyzer (Roche).

\section{STATISTICAL ANALYSIS}

Data are shown as means and SEM, and significant differences were analyzed using a non-parametric Mann-Whitney $U$-test, $p<0.05$ was accepted as statistically significant difference.

\section{RESULTS}

\section{$T_{H} 17$ CELLS SIGNATURE CYTOKINES, IL-17A AND IL-17F, mRNA TRANSCRIPTS ARE INCREASED IN THE LIVER DURING A PRIMARY $P$. CHABAUDI INFECTION}

Plasmodium chabaudi blood-stage infections in mice are characterized by an acute inflammatory response with the induction of TNF- $\alpha$, IL-1, IL- 6 , and IFN- $\gamma$ within the first 10-15 days of infection, all of which could contribute to the pathology accompanying this stage of the infection. In order to determine whether $\mathrm{T}_{\mathrm{H}} 17$ cells could play any role in controlling parasitemia and/or immunopathology we first analyzed by quantitative real-time PCR (qRT-PCR) whether mRNAs for the $\mathrm{T}_{\mathrm{H}} 17$ signature cytokines IL17A, IL-17F, and IL-22 were induced in lymphocytes and mononuclear cells in spleen and liver, respectively, during a $P$. chabaudi infection (Figure 1A).

In direct contrast to the well-described increase in IFN- $\gamma$ transcription in spleens (Stevenson et al., 1990; von der Weid and Langhorne, 1993) during the first 7-11 days of infection (Figure 1B), IL-17A mRNA levels were elevated within 1-2 days after infection but then markedly decreased over time (Figure 1B), to the levels found in naive mice, particularly at peak parasitemia (days 7-11), suggesting that the spleen environment during $P$. chabaudi infection, rich in IFN- $\gamma$ mRNA expression, may negatively regulate IL-17 expression. However, IL-17F mRNA levels were not substantially altered by the infection $( \pm 0.5$-fold change relative to naïve controls).

A markedly different response of IL-17A and IL-17F was observed in the liver, which also enlarges during malaria (Dockrell et al., 1980), coincident with an increase in IFN- $\gamma$ expression, large, and transient increases in IL-17A and IL-17F mRNA transcripts compared with naïve controls (200- and 50-fold, respectively) were detected at day 7 post-infection (Figure 1C). Similarly to the results observed in the spleen (Figure 1B), IL-22 mRNA was detectable in the liver early in the infection, but at low levels (an approximately 1.4-fold increase compared with naïve controls, Figure 1C).

Therefore, $P$. chabaudi infection induced a down-regulation of IL-17 expression in the spleen, whereas, in the liver, infection induced increased IL-17 mRNA expression, indicating a potential role for IL-17 during a blood-stage P. chabaudi infection.

\section{IN VIVO KINETICS OF IL-17A AND IL-22 EXPRESSION IN THE SPLEEN AND LIVER OF MICE INFECTED WITH $P$. CHABAUDI}

To assess whether IL-17 protein levels were consistent with the mRNA transcripts, we evaluated the kinetics of IL-17A ${ }^{\text {eYFP }}$ expression in several $\mathrm{T}$ cell populations in IL-17-fate reporter mice 


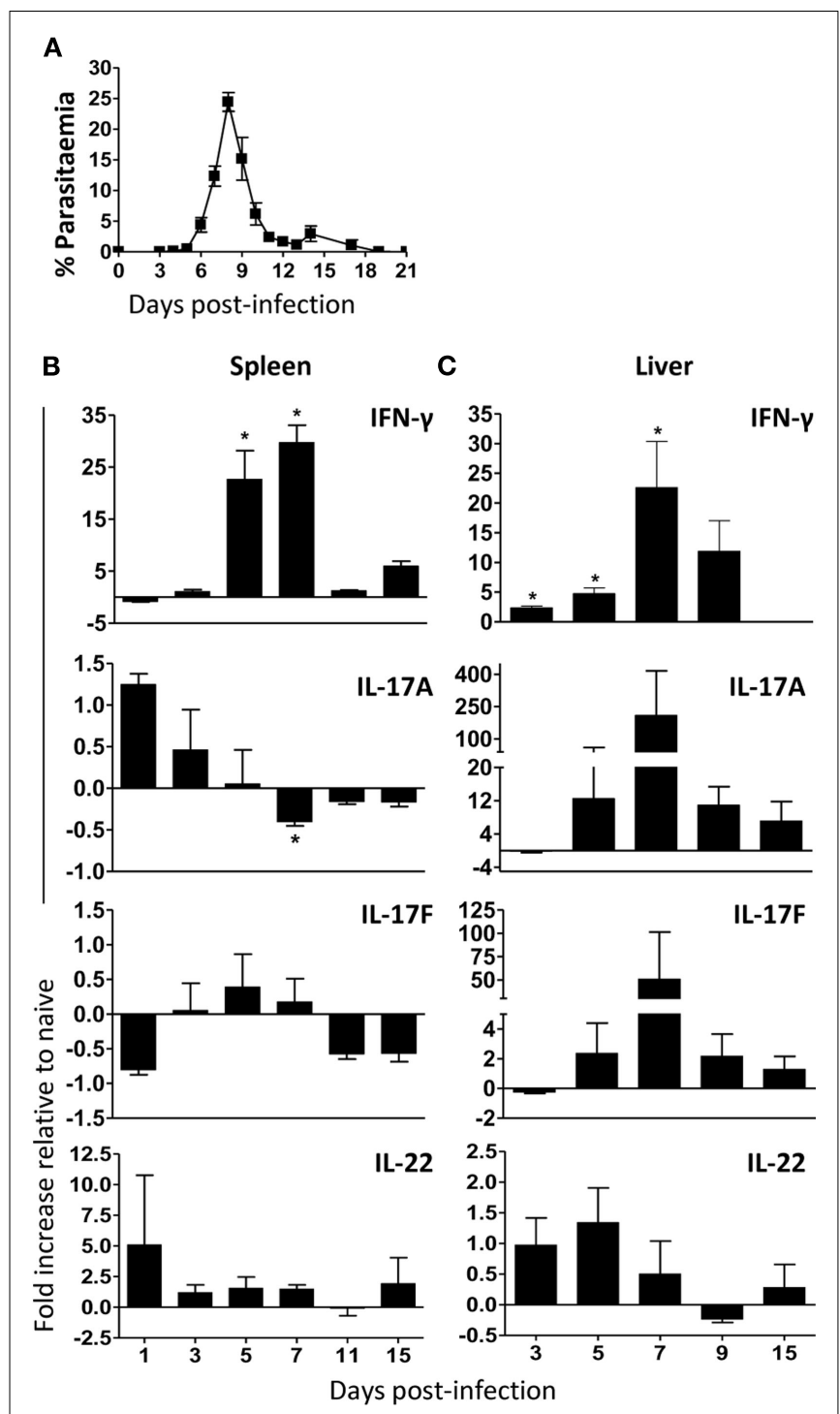

FIGURE 1 | $T_{H} 17$ cells signature cytokines, IL-17A and IL-17F, mRNA transcripts are increased in the liver during a primary $P$ chabaudi infection. C57BL/6 mice were infected with $10^{5} P$. chabaudi and sacrificed post-infection at the time points indicated. Spleen and liver mononuclear cells were harvested from naïve and infected mice and analyzed by real-time PCR. (A) Representative course of infection in C57BL/6 mice. IFN- $\gamma$, IL-17A, IL-17F, and IL-22 mRNA levels were determined in naïve and infected splenocytes (B) and liver mononuclear cells (C). Data are normalized to Ubiquitin expression. Test samples were expressed as the fold increase of gene expression compared with expression in normal uninfected mice (mean of expression from three uninfected mice were set at one) versus infected mice samples. Negative values represent levels of gene expression lower than those measured in naïve mice. Data are representative of two experiments and are obtained in groups of five mice per time points (mean \pm SEM)

(Il17a $\mathrm{a}^{\mathrm{Cre}} \mathrm{R} 26 \mathrm{R}^{\mathrm{eYFP}}$ ) infected with P. chabaudi (representative flow cytometry plots and gating strategies in Figure 2). Since the EYFP IL-17 reporter mice report any cell that has ever expressed IL-17A, it may not represent the cytokine status of the cells at the time of sampling. Therefore, we also evaluated IL-17A expression by intracellular staining in wild-type (WT) C57BL/6 mice infected with $P$. chabaudi for the same times post-infection (Figures 2 and 3). Although IL-17A transcripts were low in splenocytes throughout the course of infection, lymphocytes and mononuclear cells expressing EYFP were readily detectable and their numbers significantly increased over time in both spleen and liver (Figure 3A). By contrast, an increase in IL-17A expression by intracellular staining was only detected in liver mononuclear cells (Figure 3A), correlating with the increased IL-17 mRNA detected in the liver.

As the EYFP fate reporter marks cells that are no longer necessarily actively producing IL-17 at the times measured, there were many more IL- $17^{+}$cells in the infected reporter mice than in the C57BL/6 mice. However in both infected IL-17 reporter mice and WT C57Bl/6 mice, $\mathrm{CD}^{+}{ }^{+}$and $\mathrm{CD}^{+}{ }^{+}$T cells were the predominant sources of this cytokine in spleen and liver, respectively (shown for days 5 and 7, Figure 3A).

Although both IL-17A ${ }^{+}$and IFN- $\gamma^{+} \mathrm{T}$ cells were increased in livers of the fate reporter mice following infection, very few IL- $17^{+} \mathrm{IFN}-\gamma^{+}$double-producers were detected (Figure 3B). Therefore, although a different experimental system previously described a potential for $\mathrm{T}_{\mathrm{H}} 17$ cells to partially lose IL-17 expression and up-regulate IFN- $\gamma$ (Kurschus et al., 2010), this does not appear to be the case in this malaria infection and it is thus very unlikely that any of the IFN- $\gamma$ produced during malaria infection are derived from cells previously producing IL-17.

Although we could not detect high levels of IL-22 mRNA during $P$. chabaudi infection in either spleen or liver, they were elevated compared with controls. As IL-22 has been reported to play a critical role during acute liver inflammation (Radaeva et al., 2004; Zenewicz et al., 2007; Xu et al., 2011), we therefore investigated IL-22 production by intracellular staining of lymphocyte populations in the liver and spleen of infected C57BL/6 mice and found increased numbers of IL-22-producing cells in both organs (Figure 4A). Similar to IL-17A production, the predominant cells producing IL-22 were $\mathrm{CD} 4^{+} \mathrm{T}$ cells in the spleen and $\mathrm{CD} 8^{+} \mathrm{T}$ cells in the liver (Figures 4B,C). In agreement with a previous report showing that NKT cells are important producers of the hepatoprotective cytokine IL-22 in mouse model of hepatitis (Wahl et al., 2009), we observed that NKT cells were also significant contributors to the production of IL-22 at day 5 of the P. chabaudi infection (Figure 4A), although they represented only a very small fraction of cells present in the liver (Figure 2C). However, no IL-22 $2^{+} / \mathrm{IL}-$ $17^{+}$or IL- $22^{+} / \mathrm{IFN}-\gamma^{+}$double-producers could be detected in either the spleen or liver (Figure 4B,C), suggesting that either distinct kinetics and/or different sub-populations of $\mathrm{CD}^{+} \mathrm{T}$ cells produce these cytokines.

\section{LACK OF IL-22 BUT NOT IL-17A RESULTS IN INCREASED MORTALITY AND LIVER DAMAGE DURING A P. CHABAUDI INFECTION}

Despite the increased production of IL-17A and the greater number of $\mathrm{T}$ cells in the liver producing IL-17A during a $P$. chabaudi infection, lack of IL-17A in either the Il17a $\mathrm{a}^{\mathrm{Cre}+/+} \mathrm{R} 26 \mathrm{R}^{\mathrm{eYFP}}$ mice, or conventional $I l 17 A^{-1-}$ mice had little or no effect on parasitemia, weight loss, or hypothermia, when compared with infected control Il17a $\mathrm{a}^{\mathrm{Cre}+/-} \mathrm{R} 26 \mathrm{R}^{\mathrm{eYFP}}$ mice which express IL-17, or control C57BL/6 mice (Figure 5). Similarly, administration of neutralizing anti-IL-17A antibodies in control C57BL/6 mice did not alter 


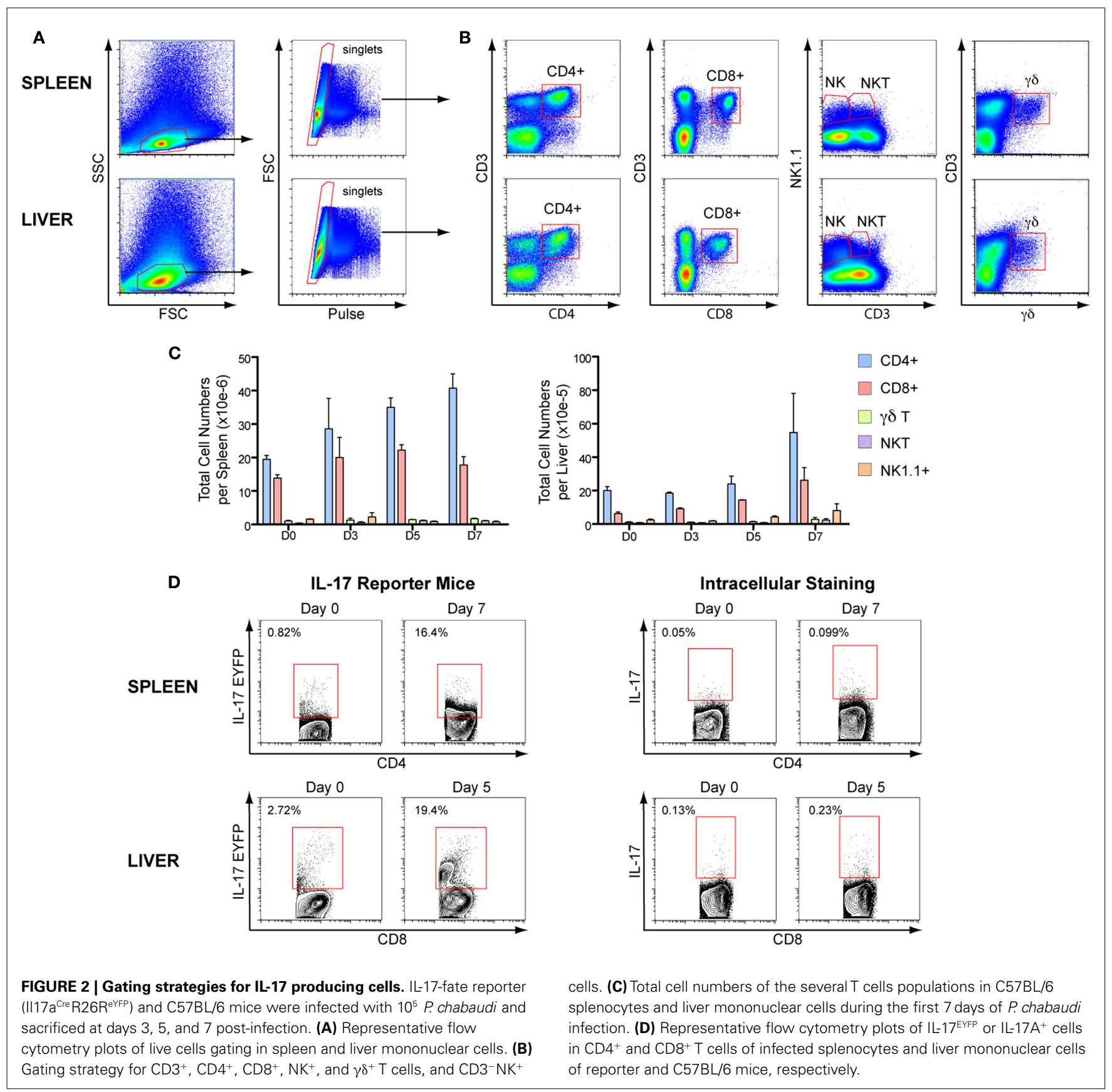

the course of the infection or any of the pathological parameters tested compared with mice receiving isotype control antibodies (data not shown).

In stark contrast, lack of IL-22 in IL-22 $\mathrm{KO}$ mice resulted in $50 \%$ mortality within 12 days after injection of $10^{5}$ P. chabaudi iRBC with significantly greater weight loss at the peak of infection (Figure 6A). Although IL-22 KO mice had some difficulty in controlling the infection with delayed clearance and increased loss of body weight compared to controls, fulminant or increased parasitemia or extreme loss of body temperature was not responsible for mortality as parasitemias and

temperature were similar in IL-22 KO (irrespective of whether or not mice died) and WT control mice (Figure 6A). There was no mortality in mice given with anti-IL-22 antibodies, and similarly to the IL-22 KO mice there was no difference in weight loss.

Experimental malaria infections in mice, including P. chabaudi infections have been shown to cause liver pathology (Mota et al., 2000; Kochar et al., 2003). As there was an increase in $\mathrm{CD}^{+}$and NKT cells producing IL-22 and IL-17 infiltrating the liver during the acute P. chabaudi infection (Figures 3 and $\mathbf{4}$ ), it was possible that in the absence of IL-22 there is an increase in liver 


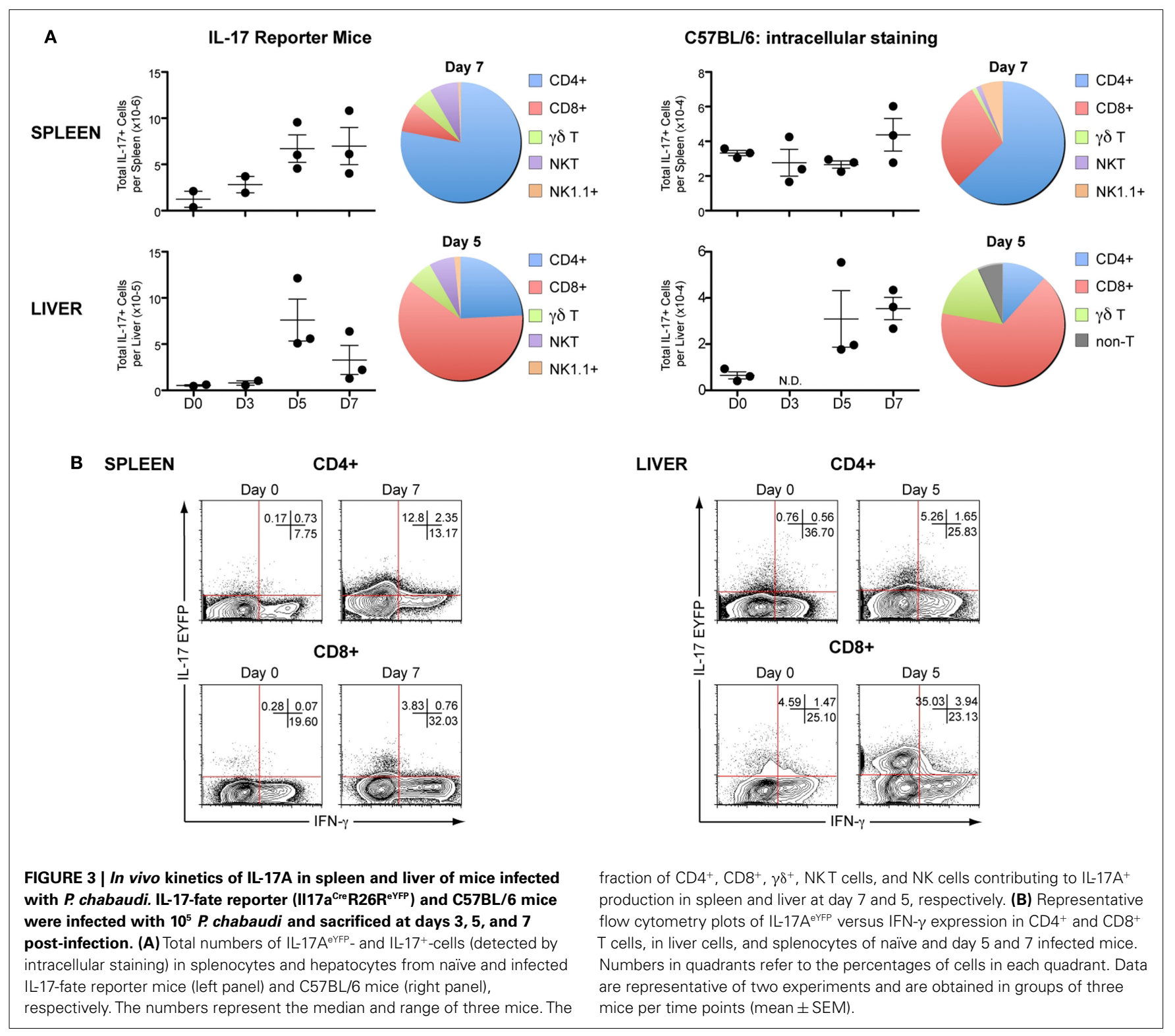

damage. We therefore measured the amount of ALT in plasma of $P$. chabaudi-infected IL-17- (Figure 5) and IL-22-deficient mice (Figures 6A,B), as an indicator of hepatocyte dysfunction (Astegiano et al., 2004).

There was a trend towards lower plasma ALT in Il17a $\mathrm{Cre}+/-\mathrm{R} 26$ $\mathrm{R}^{\text {eYFP }}$ and IL-17 KO mice compared with their WT controls during the acute phase of the $P$. chabaudi infection, however these differences were not significant, suggesting that IL-17 does not contribute in a major way to liver pathology or to its control during P. chabaudi infection (Figure 5).

Plasmodium chabaudi-infected IL-22 $\mathrm{KO}$ mice, in contrast, displayed a significant increase in ALT in the plasma in the acute infection (Figure 6A). Similarly, although there was no increase in mortality, mice given neutralizing antiIL-22 Abs also exhibited significantly greater ALT levels compared with isotype control-treated and untreated mice (Figure 6B).

We have previously shown that inactivation of regulatory cytokines such as IL-10 results in increased pathology with a proportion of mice suffering a lethal infection, caused by increased production of pro-inflammatory cytokines such as TNF- $\alpha$ and IFN- $\gamma$ (Li et al., 1999). However, unlike an infection in IL-10 KO mice there was no difference in the amounts of TNF- $\alpha$, IFN- $\gamma$, or IL- $1 \beta$ in infected IL-22 KO mice during the first 10 days of infection compared with WT mice suggesting that an enhanced inflammatory response was not the most likely cause of the mortality observed (Figure 6C).

Together these data support the idea that IL-22 may be important in controlling liver damage as a result of a $P$. chabaudi infection, and can protect mice from its potentially lethal effects.

\section{DISCUSSION}

In the present study, we have demonstrated that IL-17- and IL22-producing $\mathrm{CD}^{+} \mathrm{T}$ cells are present and increase in number 

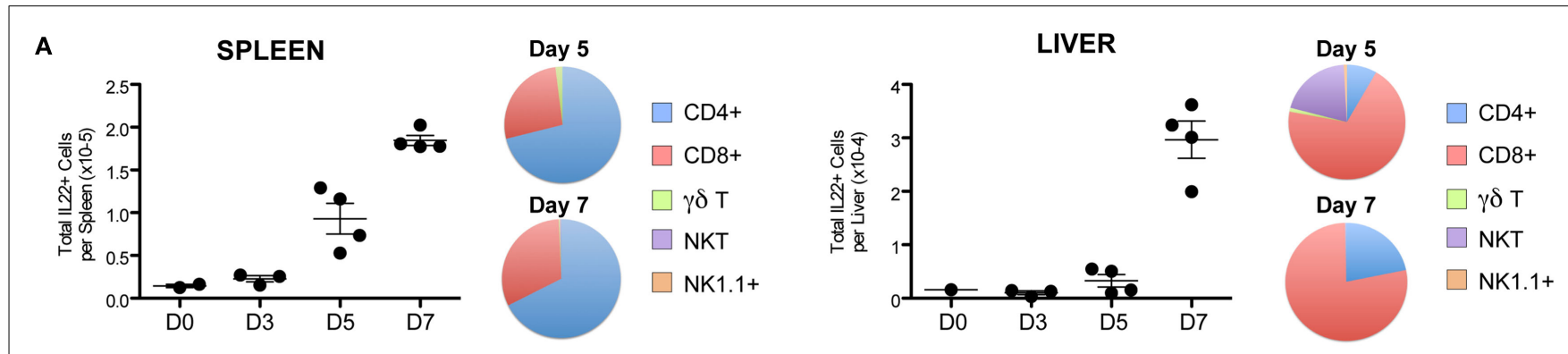

\section{B LIVER}

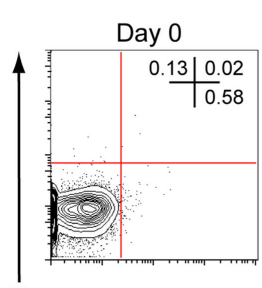

$\stackrel{\text { ำ }}{=}$
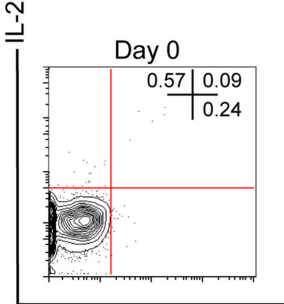

\section{SPLEEN}

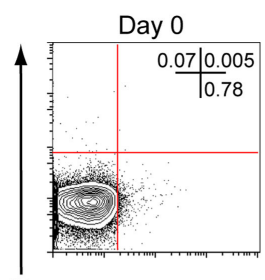

กับ

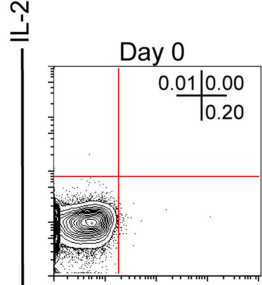

IL-17

CD4+

Day 5

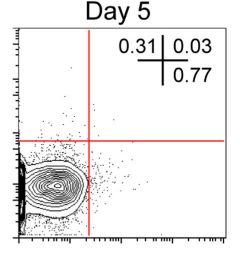

CD8+

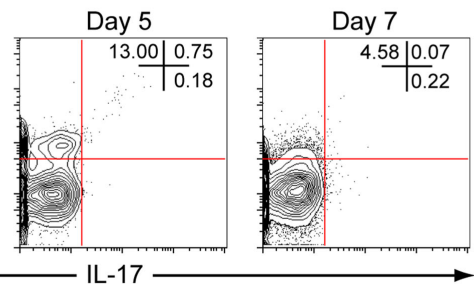

CD4+

Day 5

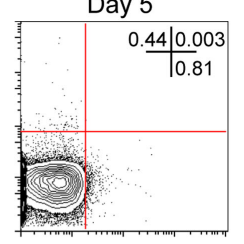

CD8+

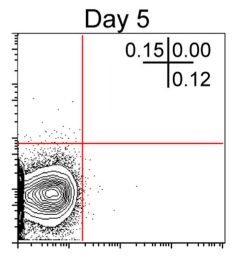

$\mathrm{IL}-17$
Day 7

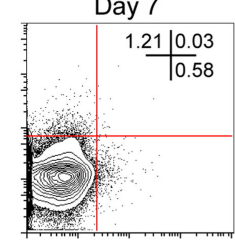

Day 7

Day 7

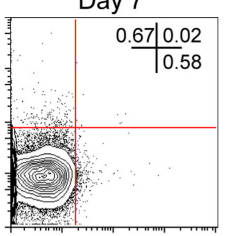

Day 7

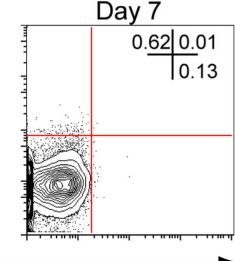

FIGURE 4 | In vivo kinetics of IL-22 in spleen and liver of mice infected with $P$. chabaudi. C57BL/6 mice were infected with $10^{5}$ $\boldsymbol{P}$ chabaudi and sacrificed at days 3,5 , and 7 post-infection. (A) Total numbers of $\mathrm{IL}_{-2} 22^{+}$cells in splenocytes and hepatocytes from naïve and infected C57BL/6 mice. The fraction of $\mathrm{CD} 4^{+}, \mathrm{CD} 8^{+}, \gamma \delta^{+}, \mathrm{NKT}$ cells, and NK cells contributing to IL-22 production in infected splenocytes and mononuclear liver cells on days 5 and 7 post-infection. The numbers
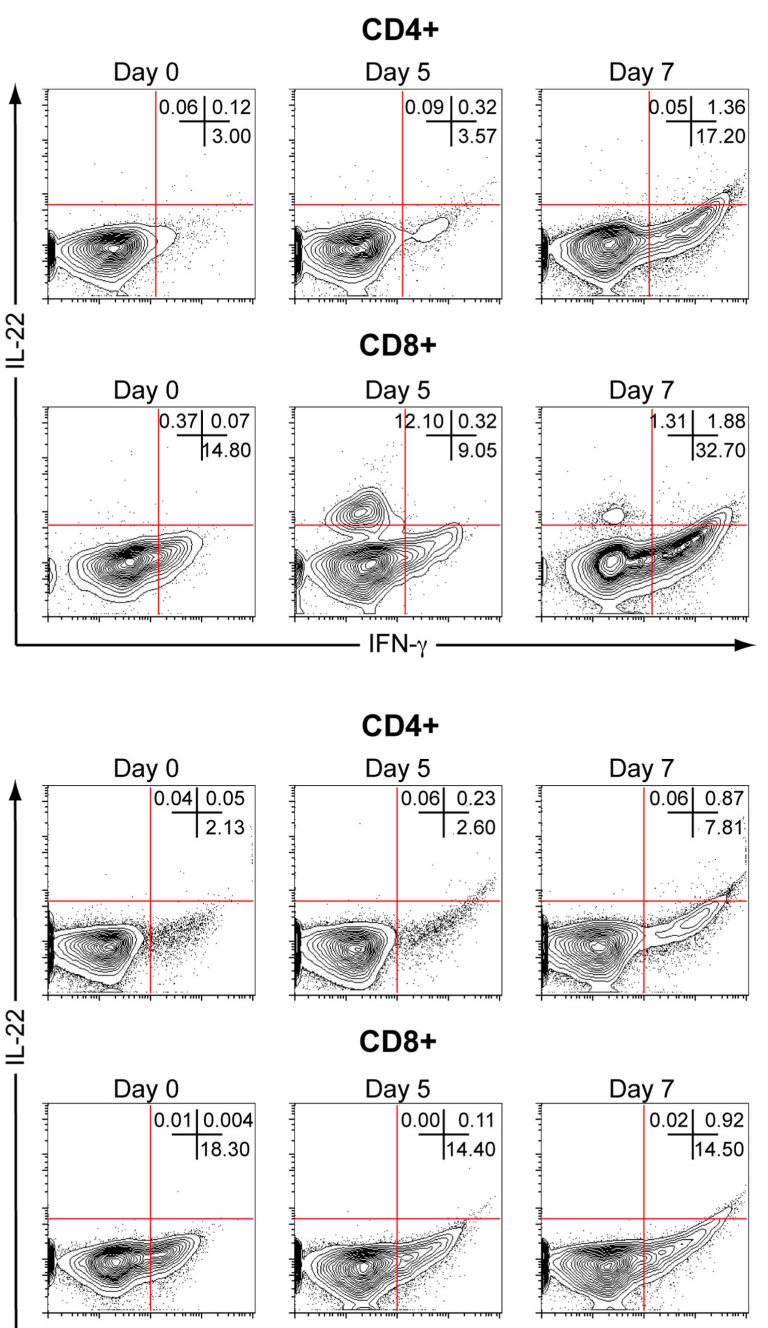

CD4+
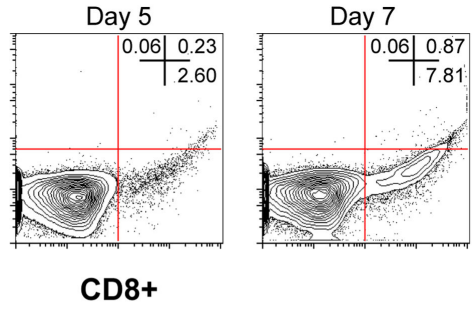

Day 5
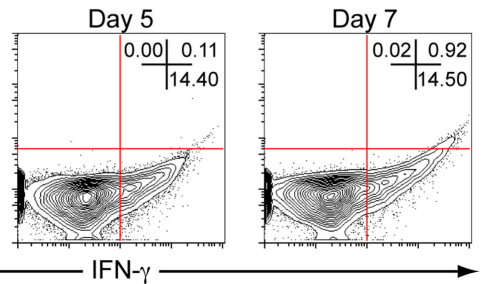

represent the median and range of four mice. Representative flow cytometry plots of IL-22 versus IL-17A (left panels) and IL-22 versus IFN- $\gamma$ (right panels) and expression in $\mathrm{CD}^{+}$, and $\mathrm{CD}^{+} \mathrm{T}$ in naïve, day 5 and 7 infected liver mononuclear cells (B) and splenocytes (C). Numbers in quadrants refer to the percentages of cells in each quadrant. Data are representative of two experiments and are from groups of four mice per time point. in the liver of C57BL/6 mice during an acute blood-stage infection with $P$. chabaudi. Importantly, IL-22 produced during a primary infection with the blood-stages of $P$. chabaudi plays vital role in controlling liver damage during a primary infection, since in its absence there is an increase in plasma ALT, and more than $50 \%$ of mice die during the first 12 days of 


\section{A}
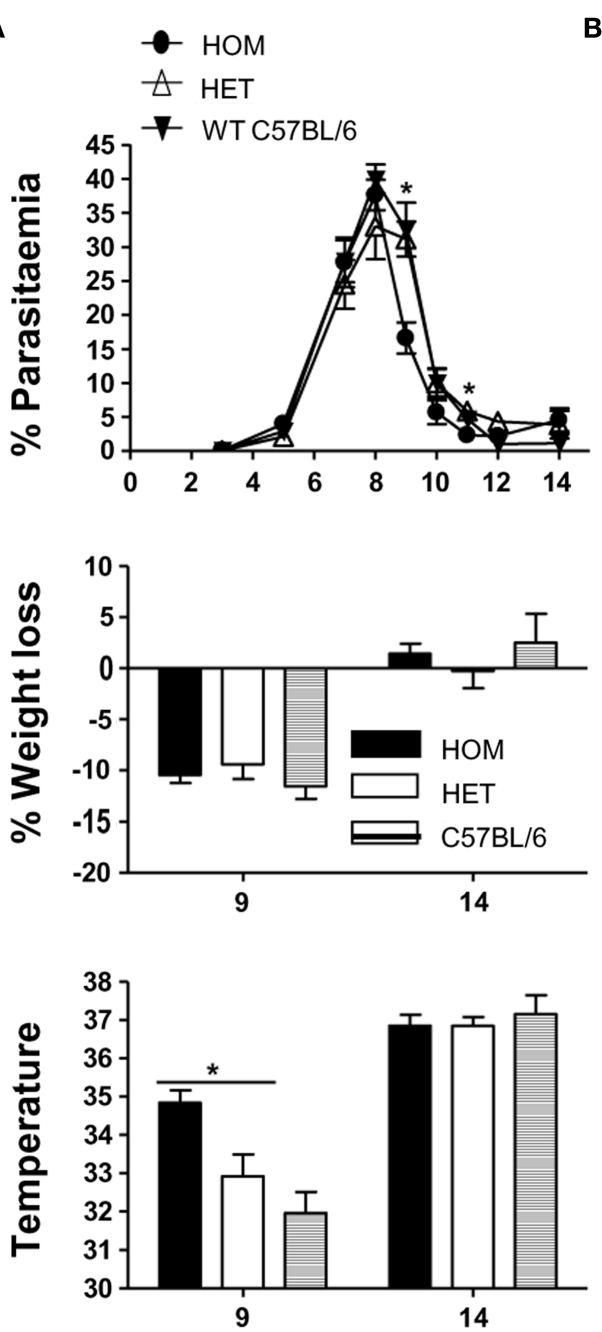

B
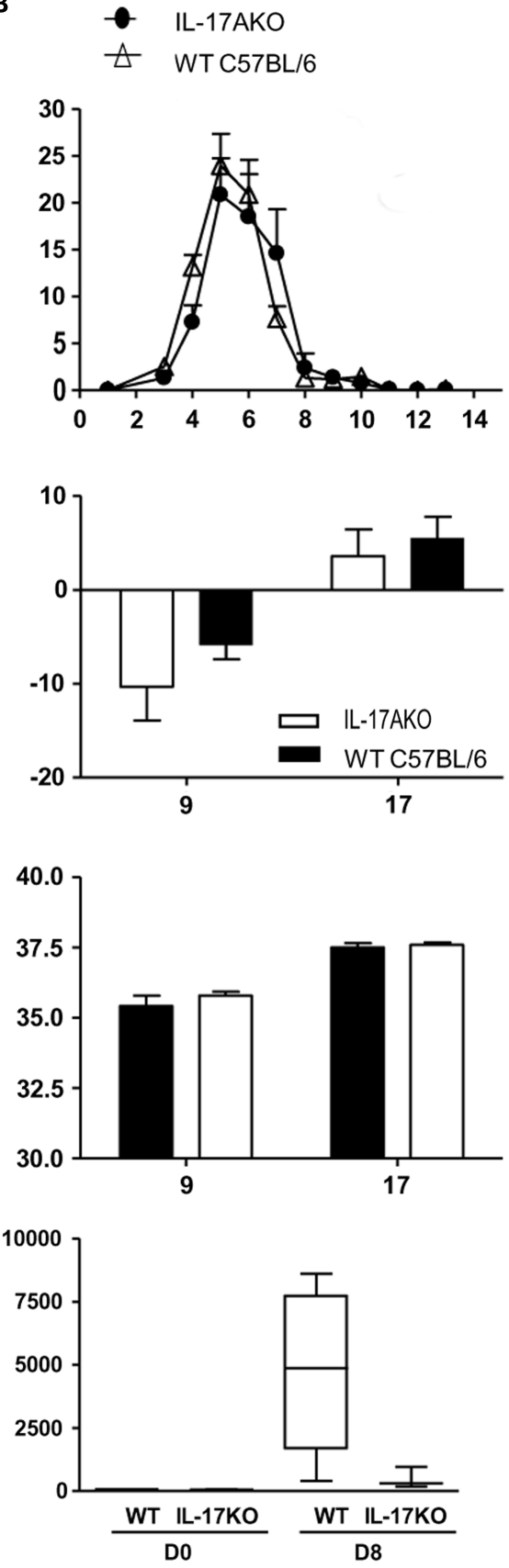

\section{Days after infection}

FIGURE 5 | Parasitemia and pathology in IL-17-fate reporter and IL-17 KO mice. (A) $1117 \mathrm{a}^{\mathrm{Cre}+/+} \mathrm{R} 26 \mathrm{R}^{\mathrm{eYFP}}$ and conventional (B) $/ 117 A^{-/-}$mice were infected with $10^{5} \mathrm{P}$. chabaudi, five mice per group. The heterozygous reporter mice in (A) also act as a control for the homozygous mice as the IL-17 gene is not deleted in these mice. WT C57BL/6 mice were used as controls in (A,B). Weight loss and hypothermia (pathology) were monitored daily. Parasitemias are presented as percentage of parasitized RBC, and the error bars represents the SEMs. Tail blood was collected to measure ALT variation during the infection, using a colorimetric end-point method (adapted from Reitman and Frankel, 1957). Briefly, $20 \mu$ l of test serum was added to $100 \mu \mathrm{l}$ of the ALT substrate and incubated for $30 \mathrm{~min}$ at $37^{\circ} \mathrm{C}$. Hundred microliters of 2,4-dinitrophenylhydrazine was then added and incubated a further $20 \mathrm{~min}$ at RT. One milliliter of $0.4 \mathrm{M} \mathrm{NaOH}$ was added to stop the reaction and the OD determined at $490 \mathrm{~nm}$. Water was used as blank. OD values were then converted into the equivalent enzyme units $(\mathrm{U} / \mathrm{ml})$ using a standard curve derived from known concentrations of a pyruvate standard. The standard curve for ALT was performed using pyruvate standards. Data are means and SEM of five mice and representative of two experiments. Significant differences are shown using a Mann-Whitney $U$-test of five mice [* significant $P$-value (0.01-0.05)]. 
A
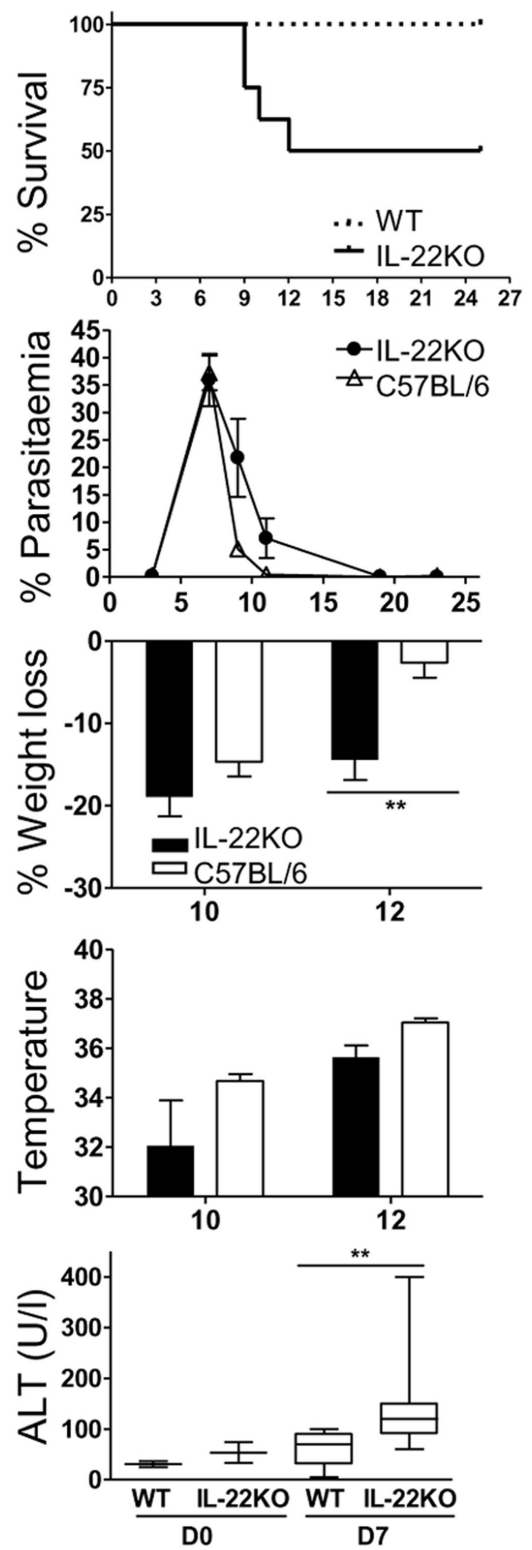

B
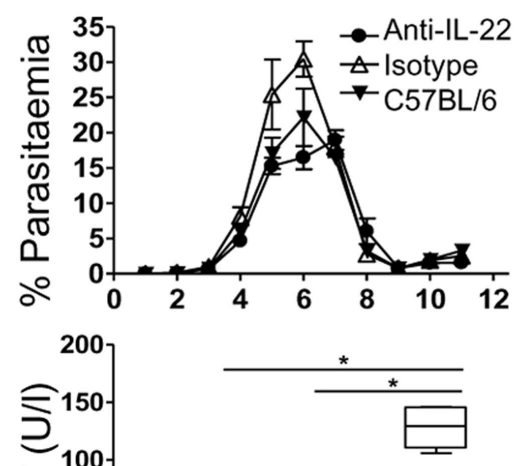

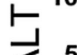

C

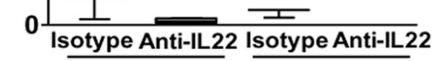

DO

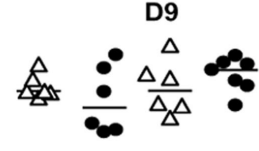

IL-1 $\beta$

TNF- $\alpha$
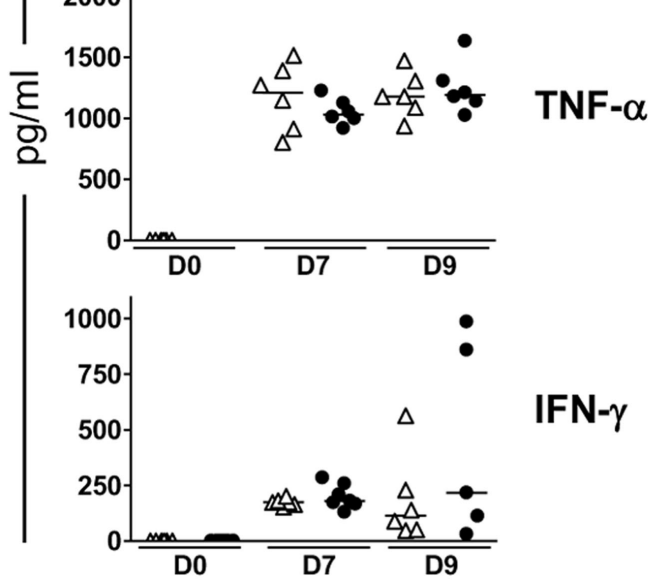

\section{Days after infection}

FIGURE 6 | Lack of IL-22 but not IL-17A results in increased mortality and liver damage during a $\boldsymbol{P}$ chabaudi infection. C57BL/6 mice were treated with either $0.5 \mathrm{mg}$ of anti-IL-22 antibody or an isotype control, every other day, from day 0 to 14 post-infection. IL-22 KO mice and anti-IL-22 treated C57BL/6 mice were infected at day 0 with $10^{5} \mathrm{P}$. chabaudi, five mice per group. Weight loss and hypothermia were monitored daily. Parasitemias are presented as percentage of parasitized RBC, and the error bars represents the SEMs. Tail blood was collected to measure ALT variation during the infection, using a
Cobas C111 chemistry analyzer. Data are means and SEM of five mice and representative of two experiments. Significant differences are shown using a Mann-Whitney $U$-test of five mice [ ${ }^{*}$ significant $P$-value $(0.01-0.05)$, **very significant $P$-value (0.001-0.01)]. (A) Survival, parasitemia, pathology, and liver damage in IL-22 KO and WT mice. (B) Parasitemia and ALT levels in anti-IL-22 treated or control mice. (C) Plasma IL-1 $\beta$, TNF- $\alpha$, and IFN- $\gamma$ levels were determined by ELISA in naïve and day 7 and 9 infected IL-22 KO mice and WT mice. The numbers and the median are represented of four mice. infection. By contrast, although IL-17A is also produced early during a $P$. chabaudi infection in the liver, largely by $\mathrm{CD}^{+} \mathrm{T}$ cells, IL-17A-deficient mice show little difference in liver damage, parasitemia, or any other indicators of pathology compared with infected control mice. Despite previous demonstrations of plasticity of $\mathrm{T}_{\mathrm{H}} 17$ cells, which can develop into disease-causing $\mathrm{T}_{\mathrm{H}} 1$ cells in autoimmune experimental allergic encephalitis (EAE) and Type I Diabetes (Bending et al., 2009; Kurschus et al., 
2010), we could find no evidence in this malaria infection that IFN- $\gamma$-producing $\mathrm{CD}^{+} \mathrm{T}$ cells had arisen from previous $\mathrm{T}_{\mathrm{H}} 17$ cells.

There is very little information on IL-22 in malaria, and no direct evidence until now that IL-22 itself had any protective effect in this infection. A large case-control study of severe malaria in a West African population identified several weak associations with individual single-nucleotide polymorphisms in the Il22 gene, and defined two IL-22 haplotypes associated with resistance (IL22 - 1394A and IL22 + 708T alleles) or susceptibility (IL22 - 1394G and the IL22 + 708C alleles; Koch et al., 2005). No data are as yet available of the effects of these polymorphisms on expression or regulation of IL-22. A recent study employing macaque models of co-infection with malaria and SHIV has demonstrated that the expansion of $\mathrm{T}_{\mathrm{H}} 17 / \mathrm{T}_{\mathrm{H}} 22$ cells attenuated malaria and avoided fatal-virus-associated malaria by inhibiting $\mathrm{T}_{\mathrm{H}} 1$ responses (Ryan-Payseur et al., 2011). Together these data indeed support our findings that IL-22 induction may be important during a malaria infection.

IL-22 has been shown to have several important roles. Its receptor is not present on hematopoietic cells but on tissues, particularly epithelial cells such as gut epithelial cells, keratinocytes, and hepatocytes (Wolk and Sabat, 2006), and it has an important cyto-protective function contributing to tissue and cell repair (Sonnenberg et al., 2011). Given our findings of increased liver damage in $P$. chabaudi infection in IL-22 KO mice, its ability to protect hepatocytes during liver inflammation (Radaeva et al., 2004; Xing et al., 2011; Xu et al., 2011) is of particular relevance.

IL-22 can be produced by many different types of lymphocytes of the innate and adaptive immune system, including CD4 ${ }^{+}$ T cells, CD8 ${ }^{+}$T cells (Zheng et al., 2007; Nograles et al., 2009), innate lymphoid cells (Taube et al., 2011), the NK-22 subset of natural killer cells (Zenewicz et al., 2008; Cella et al., 2009), $\gamma \delta^{+}$ T cells (Martin et al., 2009; Simonian et al., 2010), and CD11c ${ }^{+}$ DCs (Zheng et al., 2007). Surprisingly in our study, CD8 ${ }^{+} \mathrm{T}$ cells were a significant source of both IL-22 and IL-17 among liver mononuclear cells of infected mice. The CD8 ${ }^{+} \mathrm{T}$ cells in this $P$. chabaudi infection producing IL-17 or IL-22 are reminiscent of a recently described human population of $\mathrm{CD}^{+} \mathrm{T}$ cells (Billerbeck et al., 2010). These $\mathrm{T}_{\mathrm{C}} 17$ cells are defined by the expression of CD161 and a pattern of molecules consistent with $\mathrm{T}_{\mathrm{H}} 17$ differentiation including IL-17 and IL- 22 cytokines. In addition, $\mathrm{T}_{\mathrm{C}} 17$ cells are markedly enriched in tissue samples, such as liver, and maybe associated with protection against human Hepatitis C pathology (Billerbeck et al., 2010), in line with the known hepato-protective function of IL-22 (Radaeva et al., 2004; Xing et al., 2011; Xu et al., 2011). In our mouse model of malaria, however, we did not detect any IL-17/IL-22 double-producing cells. In this respect the $\mathrm{CD}^{+} \mathrm{T}$ cells secreting either IL-17 or IL-22 may be more similar to the IL-22-producing $\mathrm{CD}^{+}{ }^{+} \mathrm{T}$ cells, which have been shown to be distinct from $\mathrm{T}_{\mathrm{H}} 17, \mathrm{~T}_{\mathrm{H}} 1$, and $\mathrm{T}_{\mathrm{H}} 2$ cells (Trifari et al., 2009).

Induction of IL-22 in vitro depends on IL-6, IL-23, and IL$1 \beta$ (Ghoreschi et al., 2010) but unlike IL-17A, is inhibited by
TGF- $\beta$ (Rutz et al., 2011), although that has not been formally shown for these IL-22-producing $\mathrm{CD}^{+} \mathrm{T}$ cells. IL-6, TGF$\beta$, and IL-1- $\beta$ are all produced during acute malaria in mice (Artavanis-Tsakonas et al., 2003; Li et al., 2003) and humans (Walther et al., 2006), and by myeloid cells such as dendritic cells and inflammatory monocytes (Voisine et al., 2010), which have interacted with or phagocytosed hemozoin, parasite material, or iRBC (reviewed in Shio et al., 2010). Furthermore, IL-6 and TGF- $\beta$ are abundant in damaged or injured livers (Streetz et al., 2003; Knight et al., 2005), and as liver pathology has been documented during blood-stage malaria infections (Kochar et al., 2003; Devarbhavi et al., 2005; Whitten et al., 2011), it seems likely that the environment in the liver could be conducive to the differentiation of IL-17- and/or IL-22-producing $\mathrm{CD}^{+} \mathrm{T}$ cells. Therefore, IL-22-producing CD8 T cells in the liver may include both; infiltrating cells as well as liver-differentiated IL17 and IL-22-producing CD8 T cells, although this need to be determined.

The mechanism of the liver damage that is protected by IL22 in this infection is not known. In P. berghei infections of mice, different cells and molecules have been implicated, including NKT, MyD88, IL-12, IFN- $\gamma$, and free Heme (Adachi et al., 2001; Seixas et al., 2009; Findlay et al., 2010), and one study has shown that liver damage occurs independently of $\mathrm{CD}^{+} \mathrm{T}$ cells (Haque et al., 2011). Free heme has also been implicated in liver damage in P. chabaudi infections in a susceptible mouse strain (Seixas et al., 2009). Whether or not there is an additional role for other pro-inflammatory cytokines in this remains to be determined.

The signaling pathway by which IL-17 and IL-22 production are induced in $\mathrm{CD}^{+} \mathrm{T}$ cells in this $P$. chabaudi infection has still to be elucidated. As we only evaluated mice lacking IL-22, it is unclear whether, similarly to $\mathrm{CD} 4^{+} \mathrm{T}$ cells (Veldhoen et al., 2008), AHR and Notch signaling are required for IL-22 expression in the liver $\mathrm{CD}^{+} \mathrm{T}$ cells in this malaria infection, and further studies are required to delineate whether this pathway is a key mechanism involved in protection from liver damage during a primary $P$. chabaudi infection via the induction of IL-22-producing $\mathrm{CD}^{+} \mathrm{T}$ cells.

In conclusion, we propose that the IL- $22^{+} \mathrm{CD} 8^{+} \mathrm{T}$ cells, which appear in the liver in this $P$. chabaudi infection prevent or ameliorate potential toxic damage to liver cells. The relevance of these findings to human severe malaria remains to be established. As hepatic dysfunction can be a significant feature of human malaria it would be important to relate our findings to the IL-22 gene polymorphisms found to be associated with resistance or susceptibility to $P$. falciparum malaria, as well as to the magnitude of IL-22 response in severe and mild disease.

\section{ACKNOWLEDGMENTS}

This work was supported by the Medical Research Council, United Kingdom (MRC file reference: U117584248), and is part of the EviMalar European Network of Excellence supported by the Framework 7 programme of the European Union. BM was in receipt of a MRC PhD Studentship. 


\section{REFERENCES}

Adachi, K., Tsutsui, H., Kashiwamura, S., Seki, E., Nakano, H., Takeuchi, O., Takeda, K., Okumura, K., Van Kaer, L., Okamura, H., Akira, S., and Nakanishi, K. (2001). Plasmodium berghei infection in mice induces liver injury by an IL-12- and tolllike receptor/myeloid differentiation factor 88-dependent mechanism. J. Immunol. 167, 5928-5934.

Aggarwal, S., Ghilardi, N., Xie, M. H., De Sauvage, F. J., and Gurney, A. L. (2003). Interleukin-23 promotes a distinct CD4 $\mathrm{T}$ cell activation state characterized by the production of interleukin-17. J. Biol. Chem. 278, 1910-1914.

Alam, M. S., Maekawa, Y., Kitamura, A., Tanigaki, K., Yoshimoto, T., Kishihara, K., and Yasutomo, K. (2010). Notch signaling drives IL-22 secretion in CD4+ $\mathrm{T}$ cells by stimulating the aryl hydrocarbon receptor. Proc. Natl. Acad. Sci. U.S.A. 107, 5943-5948.

Annunziato, F., Cosmi, L., Santarlasci, V., Maggi, L., Liotta, F., Mazzinghi, B., Parente, E., Fili, L., Ferri, S., Frosali, F., Giudici, F., Romagnani, P., Parronchi, P., Tonelli, F., Maggi, E., and Romagnani, S. (2007). Phenotypic and functional features of human Th17 cells. J. Exp. Med. 204, 1849-1861.

Artavanis-Tsakonas, K., Tongren, J. E., and Riley, E. M. (2003). The war between the malaria parasite and the immune system: immunity, immunoregulation and immunopathology. Clin. Exp. Immunol. 133, 145-152.

Astegiano, M., Sapone, N., Demarchi, B., Rossetti, S., Bonardi, R., and Rizzetto, M. (2004). Laboratory evaluation of the patient with liver disease. Eur. Rev. Med. Pharmacol. Sci. 8, 3-9.

Aujla, S. J., Chan, Y. R., Zheng, M., Fei, M., Askew, D. J., Pociask, D. A., Reinhart, T. A., Mcallister, F., Edeal, J., Gaus, K., Husain, S., Kreindler, J. L., Dubin, P. J., Pilewski, J. M., Myerburg, M. M., Mason, C. A., Iwakura, Y., and Kolls, J. K. (2008). IL-22 mediates mucosal host defense against Gram-negative bacterial pneumonia. Nat. Med. 14, 275-281.

Awasthi, A., and Kuchroo, V. K. (2009). Th17 cells: from precursors to players in inflammation and infection. Int. Immunol. 21, 489-498.

Bending, D., De La Pena, H., Veldhoen, M., Phillips, J. M., Uyttenhove, C., Stockinger, B., and Cooke, A. (2009). Highly purified Th17 cells from BDC2.5NOD mice convert into Th1-like cells in NOD/SCID recipient mice. J. Clin. Invest. 119, 565-572.

Billerbeck, E., Kang, Y. H., Walker, L., Lockstone, H., Grafmueller, S., Fleming, V., Flint, J., Willberg, C. B., Bengsch, B., Seigel, B., Ramamurthy, N., Zitzmann, N., Barnes, E. J., Thevanayagam, J., Bhagwanani, A., Leslie, A., Oo, Y. H., Kollnberger, S., Bowness, P., Drognitz, O., Adams, D. H., Blum, H. E., Thimme, R., and Klenerman, P. (2010). Analysis of CD161 expression on human CD8+ $\mathrm{T}$ cells defines a distinct functional subset with tissue-homing properties. Proc. Natl. Acad. Sci. U.S.A. 107, 3006-3011.

Cella, M., Fuchs, A., Vermi, W., Facchetti, F., Otero, K., Lennerz, J. K., Doherty, J. M., Mills, J. C., and Colonna, M. (2009). A human natural killer cell subset provides an innate source of IL-22 for mucosal immunity. Nature 457, 722-725.

Devarbhavi, H., Alvares, J. F., and Kumar, K. S. (2005). Severe falciparum malaria simulating fulminant hepatic failure. Mayo Clin. Proc. 80, 355-358.

Dockrell, H. M., De Souza, J. B., and Playfair, J. H. (1980). The role of the liver in immunity to bloodstage murine malaria. Immunology 41, 421-430.

Dumoutier, L., De Meester, C., Tavernier, J., and Renauld, J. C. (2009). New activation modus of STAT3: a tyrosine-less region of the interleukin-22 receptor recruits STAT3 by interacting with its coiledcoil domain. J. Biol. Chem. 284, 26377-26384.

Findlay, E. G., Greig, R., Stumhofer, J. S., Hafalla, J. C., De Souza, J. B., Saris, C. J., Hunter, C. A., Riley, E. M., and Couper, K. N. (2010). Essential role for IL-27 receptor signaling in prevention of Th1mediated immunopathology during malaria infection. J. Immunol. 185, 2482-2492.

Ghoreschi, K., Laurence, A., Yang, X. P., Tato, C. M., Mcgeachy, M. J., Konkel, J. E., Ramos, H. L., Wei, L., Davidson, T. S., Bouladoux, N., Grainger, J. R., Chen, Q., Kanno, Y., Watford, W. T., Sun, H. W., Eberl, G., Shevach, E. M., Belkaid, Y., Cua, D. J., Chen, W., and O'Shea, J. J. (2010). Generation of pathogenic $\mathrm{T}(\mathrm{H}) 17$ cells in the absence of TGF-beta signalling. Nature 467, 967-971.

Goto, M., Murakawa, M., KadoshimaYamaoka, K., Tanaka, Y., Nagahira, K., Fukuda, Y., and Nishimura, T. (2009). Murine NKT cells produce
Th17 cytokine interleukin-22. Cell. Immunol. 254, 81-84.

Haque, A., Best, S. E., Amante, F. H., Ammerdorffer, A., De Labastida, F. Pereira, T., Ramm, G. A., and Engwerda, C. R. (2011). High parasite burdens cause liver damage in mice following Plasmodium berghei ANKA infection independently of CD8(+) T cell-mediated immune pathology. Infect. Immun. 79, 1882-1888.

Hirota, K., Duarte, J. H., Veldhoen, M. Hornsby, E., Li, Y., Cua, D. J., Ahlfors, H., Wilhelm, C., Tolaini, M., Menzel, U., Garefalaki, A., Potocnik, A. J., and Stockinger, B. (2011). Fate mapping of IL-17-producing T cells in inflammatory responses. Nat. Immunol. 12, 255-263.

Ivanov, I. I., Mckenzie, B. S., Zhou, L., Tadokoro, C. E., Lepelley, A., Lafaille, J. J., Cua, D. J., and Littman, D. R. (2006). The orphan nuclear receptor RORgamma t directs the differentiation program of proinflammatory IL-17+ T helper cells. Cell 126, 1121-1133.

Kelly, M. N., Kolls, J. K., Happel, K. Schwartzman, J. D., Schwarzenberger, P., Combe, C., Moretto, M., and Khan, I. A. (2005). Interleukin-17/interleukin-17 receptor-mediated signaling is important for generation of an optimal polymorphonuclear response against Toxoplasma gondii infection. Infect. Immun. 73, 617-621.

Knight, B., Matthews, V. B., Akhurst, B., Croager, E. J., Klinken, E., Abraham, L. J., Olynyk, J. K., and Yeoh, G. (2005). Liver inflammation and cytokine production, but not acute phase protein synthesis, accompany the adult liver progenitor (oval) cell response to chronic liver injury. Immunol. Cell Biol. 83, 364-374.

Koch, O., Rockett, K., Jallow, M., Pinder, M., Sisay-Joof, F., and Kwiatkowski, D. (2005). Investigation of malaria susceptibility determinants in the IFNG/IL26/IL22 genomic region. Genes Immun. 6, 312-318

Kochar, D. K., Agarwal, P., Kochar, S. K., Jain, R., Rawat, N., Pokharna, R. K., Kachhawa, S., and Srivastava, T. (2003). Hepatocyte dysfunction and hepatic encephalopathy in Plasmodium falciparum malaria. QJM 96, 505-512.

Komiyama, Y., Nakae, S., Matsuki, T. Nambu, A., Ishigame, H., Kakuta, S. Sudo, K., and Iwakura, Y. (2006). IL-17 plays an important role in the development of experimental autoimmune encephalomyelitis. J. Immunol. 177, 566-573.

Kreymborg, K., Etzensperger, R., Dumoutier, L., Haak, S., Rebollo, A.,
Buch, T., Heppner, F. L., Renauld, J. C., and Becher, B. (2007). IL-22 is expressed by Th17 cells in an IL-23-dependent fashion, but not required for the development of autoimmune encephalomyelitis. J. Immunol. 179, 8098-8104.

Kurschus, F. C., Croxford, A. L., Heinen, A. P., Wortge, S., Ielo, D., and Waisman, A. (2010). Genetic proof for the transient nature of the Th17 phenotype. Eur. J. Immunol. 40, 3336-3346.

Langhorne, J., Ndungu, F. M., Sponaas, A. M., and Marsh, K. (2008). Immunity to malaria: more questions than answers. Nat. Immunol. 9 , 725-732.

Langrish, C. L., Chen, Y., Blumenschein, W. M., Mattson, J., Basham, B., Sedgwick, J. D., Mcclanahan, T., Kastelein R. A., and Cua, D. J. (2005). IL23 drives a pathogenic $\mathrm{T}$ cell population that induces autoimmune inflammation. J. Exp. Med. 201, 233-240.

Lee, Y. K., Turner, H., Maynard, C. L., Oliver, J. R., Chen, D., Elson, C. O., and Weaver, C. T. (2009). Late developmental plasticity in the $\mathrm{T}$ helper 17 lineage. Immunity 30, 92-107.

Li, C., Corraliza, I., and Langhorne, J. (1999). A defect in interleukin-10 leads to enhanced malarial disease in Plasmodium chabaudi chabaudi infection in mice. Infect. Immun. 67, 4435-4442.

Li, C., Sanni, L. A., Omer, F., Riley, E., and Langhorne, J. (2003). Pathology of Plasmodium chabaudi chabaudi infection and mortality in interleukin-10-deficient mice are ameliorated by anti-tumor necrosis factor alpha and exacerbated by anti-transforming growth factor beta antibodies. Infect. Immun. 71, 4850-4856.

Liang, S. C., Tan, X. Y., Luxenberg, D. P., Karim, R., Dunussi-Joannopoulos K., Collins, M., and Fouser, L. A (2006). Interleukin (IL)-22 and IL17 are coexpressed by Th17 cells and cooperatively enhance expression of antimicrobial peptides. J. Exp. Med. 203, 2271-2279.

Ma, H. L., Liang, S., Li, J., Napierata, L., Brown, T., Benoit, S., Senices, M., Gill, D., Dunussi-Joannopoulos K., Collins, M., Nickerson-Nutter, C., Fouser, L. A., and Young, D. A. (2008). IL-22 is required for Th17 cell-mediated pathology in a mouse model of psoriasis-like skin inflammation. J. Clin. Invest. 118, 597-607.

Mangan, P. R., Harrington, L. E., O'Quinn, D. B., Helms, W. S., Bullard, D. C., Elson, C. O., Hatton, 
R. D., Wahl, S. M., Schoeb, T. R., and Weaver, C. T. (2006). Transforming growth factor-beta induces development of the $\mathrm{T}(\mathrm{H}) 17$ lineage. Nature 441, 231-234.

Martin, B., Hirota, K., Cua, D. J., Stockinger, B., and Veldhoen, M. (2009). Interleukin-17-producing gamma delta $\mathrm{T}$ cells selectively expand in response to pathogen products and environmental signals. Immunity 31, 321-330.

Matthews, K., Wilkinson, K. A., Kalsdorf, B., Roberts, T., Diacon, A., Walzl, G., Wolske, J., Ntsekhe, M., Syed, F., Russell, J., Mayosi, B. M., Dawson, R., Dheda, K., Wilkinson, R. J., Hanekom, W. A., and Scriba, T. J. (2011). Predominance of interleukin-22 over interleukin17 at the site of disease in human tuberculosis. Tuberculosis (Edinb.) 91, 587-593.

Meding, S. J., and Langhorne, J. (1991). $\mathrm{CD} 4+\mathrm{T}$ cells and $\mathrm{B}$ cells are necessary for the transfer of protective immunity to Plasmodium chabaudi chabaudi. Eur. J. Immunol. 21, 1433-1438.

Moseley, T. A., Haudenschild, D. R., Rose, L., and Reddi, A. H. (2003). Interleukin-17 family and IL-17 receptors. Cytokine Growth Factor Rev. 14, 155-174.

Mota, M. M., Jarra, W., Hirst, E., Patnaik, P. K., and Holder, A. A. (2000). Plasmodium chabaudiinfected erythrocytes adhere to $\mathrm{CD} 36$ and bind to microvascular endothelial cells in an organspecific way. Infect. Immun. 68 , 4135-4144.

Nograles, K. E., Zaba, L. C., Shemer, A., Fuentes-Duculan, J., Cardinale, I., Kikuchi, T., Ramon, M., Bergman, R., Krueger, J. G., and Guttman-Yassky, E. (2009). IL-22-producing "T22" T cells account for upregulated IL-22 in atopic dermatitis despite reduced IL-17-producing TH17 T cells. J. Allergy Clin. Immunol. 123, 1244-1252.

O'Shea, J. J., and Paul, W. E. (2010). Mechanisms underlying lineage commitment and plasticity of helper CD4+ T cells. Science 327, 1098-1102.

Pfaffl, M. W. (2001). A new mathematical model for relative quantification in real-time RT- PCR. Nucleic Acids Res. 29, e45.

Pitta, M. G., Romano, A., Cabantous, S., Henri, S., Hammad, A., Kouriba, B., Argiro, L., El Kheir, M., Bucheton, B., Mary, C., El-Safi, S. H., and Dessein, A. (2009). IL-17 and IL-22 are associated with protection against human kala azar caused by Leishmania donovani. J. Clin. Invest. 119, 2379-2387.

Radaeva, S., Sun, R., Pan, H. N., Hong, F., and Gao, B. (2004). Interleukin 22 (IL-22) plays a protective role in T cell-mediated murine hepatitis: IL22 is a survival factor for hepatocytes via STAT3 activation. Hepatology 39, 1332-1342.

Reitman, S., and Frankel, S. (1957). A colorimetric method for the determination of serum glutamic oxalacetic and glutamic pyruvic transaminases. Am. J. Clin. Pathol. 28, 56-63.

Ren, J., Feng, Z., Lv, Z., Chen, X., and Li, J. (2011). Natural killer-22 cells in the synovial fluid of patients with rheumatoid arthritis are an innate source of interleukin 22 and tumor necrosis factor-alpha. J. Rheumatol. $38,2112-2118$.

Rutz, S., Noubade, R., Eidenschenk, C., Ota, N., Zeng, W., Zheng, Y., Hackney, J., Ding, J., Singh, H., and Ouyang, W. (2011). Transcription factor c-Maf mediates the TGF-beta-dependent suppression of IL-22 production in $\mathrm{T}(\mathrm{H}) 17$ cells. Nat. Immunol. 12, 1238-1245.

Ryan-Payseur, B., Ali, Z., Huang, D., Chen, C. Y., Yan, L., Wang, R. C., Collins, W. E., Wang, Y., and Chen, Z. W. (2011). Virus infection stages and distinct Th1 or Th17/Th22 Tcell responses in malaria/SHIV coinfection correlate with different outcomes of disease. J. Infect. Dis. 204, 1450-1462.

Schmidt, J. V., and Bradfield, C. A. (1996). Ah receptor signaling pathways. Annu. Rev. Cell Dev. Biol. 12, 55-89.

Seixas, E., Gozzelino, R., Chora, A., Ferreira, A., Silva, G., Larsen, R., Rebelo, S., Penido, C., Smith, N. R., Coutinho, A., and Soares, M. P. (2009). Heme oxygenase1 affords protection against noncerebral forms of severe malaria. Proc. Natl. Acad. Sci. U.S.A. 106, 15837-15842.

Shio, M. T., Kassa, F. A., Bellemare, M. J., and Olivier, M. (2010). Innate inflammatory response to the malarial pigment hemozoin. Microbes Infect. 12, 889-899.

Simonian, P. L., Wehrmann, F., Roark, C. L., Born, W. K., O’Brien, R. L., and Fontenot, A. P. (2010). gammadelta $\mathrm{T}$ cells protect against lung fibrosis via IL-22. J. Exp. Med. 207, 2239-2253.

Sonnenberg, G. F., Fouser, L. A., and Artis, D. (2011). Border patrol: regulation of immunity, inflammation and tissue homeostasis at barrier surfaces by IL-22. Nat. Immunol. 12 , 383-390.

Steinman, L. (2007). A brief history of $\mathrm{T}(\mathrm{H}) 17$, the first major revision in the $\mathrm{T}(\mathrm{H}) 1 / \mathrm{T}(\mathrm{H}) 2$ hypothesis of $\mathrm{T}$ cell-mediated tissue damage. Nat. Med. 13 139-145.

Stevenson, M. M., Tam, M. F., Belosevic, M., Van Der Meide, P. H., and Podoba, J. E. (1990) Role of endogenous gamma interferon in host response to infection with blood-stage Plasmodium chabaudi AS. Infect. Immun. 58, 3225-3232.

Streetz, K. L., Tacke, F., Leifeld, L., Wustefeld, T., Graw, A., Klein, C., Kamino, K., Spengler, U., Kreipe, H., Kubicka, S., Muller, W., Manns, M. P., and Trautwein, C. (2003). Interleukin 6/gp130-dependent pathways are protective during chronic liver diseases. Hepatology 38 , 218-229.

Taube, C., Tertilt, C., Gyulveszi, G., Dehzad, N., Kreymborg, K., Schneeweiss, K., Michel, E., Reuter, S., Renauld, J. C., Arnold-Schild, D., Schild, H., Buhl, R., and Becher, B. (2011). IL-22 is produced by innate lymphoid cells and limits inflammation in allergic airway disease. PLoS ONE 6, e21799. doi:10.1371/journal.pone.0021799

Trifari, S., Kaplan, C. D., Tran, E. H., Crellin, N. K., and Spits, H. (2009). Identification of a human helper $\mathrm{T}$ cell population that has abundant production of interleukin 22 and is distinct from $\mathrm{T}(\mathrm{H})-17, \mathrm{~T}(\mathrm{H}) 1$ and $\mathrm{T}(\mathrm{H}) 2$ cells. Nat. Immunol. 10 864-871.

Tupin, E., and Kronenberg, M. (2006). Activation of natural killer $\mathrm{T}$ cells by glycolipids. Meth. Enzymol. 417, 185-201.

Unkeless, J. C. (1979). Characterization of a monoclonal antibody directed against mouse macrophage and lymphocyte Fc receptors. J. Exp. Med. $150,580-596$

Uyttenhove, C., and Van Snick, J. (2006). Development of an anti-IL-17A auto-vaccine that prevents experimental auto-immune encephalomyelitis. Eur. J. Immunol. 36, 2868-2874.

Veldhoen, M., Hirota, K., Westendorf, A. M., Buer, J., Dumoutier, L., Renauld, J. C., and Stockinger, B. (2008). The aryl hydrocarbon receptor links TH17-cell-mediated autoimmunity to environmental toxins. Nature 453 , 106-109.

Veldhoen, M., Hocking, R. J., Flavell, R. A., and Stockinger, B. (2006).
Signals mediated by transforming growth factor-beta initiate autoimmune encephalomyelitis, but chronic inflammation is needed to sustain disease. Nat. Immunol. 7, 1151-1156.

Voisine, C., Mastelic, B., Sponaas, A. M., and Langhorne, J. (2010). Classical CD11c+ dendritic cells, not plasmacytoid dendritic cells, induce $\mathrm{T}$ cell responses to Plasmodium chabaudi malaria. Int. J. Parasitol. 40, 711-719.

von der Weid, T., and Langhorne, J. (1993). The roles of cytokines produced in the immune response to the erythrocytic stages of mouse malarias. Immunobiology 189, 397-418.

Wahl, C., Wegenka, U. M., Leithauser F., Schirmbeck, R., and Reimann J. (2009). IL-22-dependent attenuation of $\mathrm{T}$ cell-dependent (ConA) hepatitis in herpes virus entry mediator deficiency. J. Immunol. 182, 4521-4528.

Walther, M., Woodruff, J., Edele, F., Jeffries, D., Tongren, J. E., King, E., Andrews, L., Bejon, P., Gilbert, S. C., De Souza, J. B., Sinden, R., Hill, A. V., and Riley, E. M. (2006). Innate immune responses to human malaria: heterogeneous cytokine responses to blood-stage Plasmodium falciparum correlate with parasitological and clinical outcomes. J. Immunol. 177, 5736-5745.

Whitten, R., Milner, D. A. Jr., Yeh, M. M., Kamiza, S., Molyneux, M. E., and Taylor, T. E. (2011). Liver pathology in Malawian children with fatal encephalopathy. Hum. Pathol. 42, 1230-1239.

Wolk, K., Kunz, S., Witte, E., Friedrich, M., Asadullah, K., and Sabat, R. (2004). IL-22 increases the innate immunity of tissues. Immunity 21 , 241-254.

Wolk, K., and Sabat, R. (2006). Interleukin-22: a novel T- and NKcell derived cytokine that regulates the biology of tissue cells. Cytokine Growth Factor Rev. 17, 367-380.

Xing, W. W., Zou, M. J., Liu, S., Xu, T., Gao, J., Wang, J. X., and $\mathrm{Xu}, \mathrm{D}$. G. (2011). Hepatoprotective effects of IL-22 on fulminant hepatic failure induced by $\mathrm{d}$-galactosamine and lipopolysaccharide in mice. Cytokine 56, 174-179.

Xu, M., Morishima, N., Mizoguchi, I., Chiba, Y., Fujita, K., Kuroda M., Iwakura, Y., Cua, D. J., Yasutomo, K., Mizuguchi, J., and Yoshimoto, T. (2011). Regulation of the development of acute hepatitis by IL-23 through IL-22 and IL-17 
production. Eur. J. Immunol. 41, 2828-2839.

Zenewicz, L. A., Yancopoulos, G. D., Valenzuela, D. M., Murphy, A. J., Karow, M., and Flavell, R. A. (2007). Interleukin-22 but not interleukin-17 provides protection to hepatocytes during acute liver inflammation. Immunity 27, 647-659.

Zenewicz, L. A., Yancopoulos, G. D., Valenzuela, D. M., Murphy, A. J., Stevens, S., and Flavell, R. A. (2008). Innate and adaptive interleukin22 protects mice from inflammatory bowel disease. Immunity 29, 947-957.
Zhang, Y., Cobleigh, M. A., Lian, J. Q., Huang, C. X., Booth, C. J., Bai, X. F., and Robek, M. D. (2011). A proinflammatory role for interleukin-22 in the immune response to hepatitis B virus. Gastroenterology 141, 1897-1906.

Zheng, Y., Danilenko, D. M., Valdez, P., Kasman, I., EasthamAnderson, J., Wu, J., and Ouyang, W. (2007). Interleukin-22, a $\mathrm{T}(\mathrm{H}) 17$ cytokine, mediates IL23-induced dermal inflammation and acanthosis. Nature 445, 648-651.

Zhou, L., Chong, M. M., and Littman, D. R. (2009). Plasticity of CD4+ T cell lineage differentiation. Immunity 30, 646-655.

Conflict of Interest Statement: The authors declare that the research was conducted in the absence of any commercial or financial relationships that could be construed as a potential conflict of interest.

Received: 19 January 2012; accepted: 03 April 2012; published online: 25 Apri 2012.

Citation: Mastelic B, do Rosario APF, Veldhoen M, Renauld JC, Jarra W, Sponaas A-M, Roetynck S, Stockinger B and Langhorne J (2012) IL-22 protects against liver pathology and lethality of an experimental blood-stage malaria infection. Front. Immun. 3:85. doi: 10.3389/fimmu.2012.00085

This article was submitted to Frontiers in Inflammation, a specialty of Frontiers in Immunology.

Copyright (c) 2012 Mastelic, do Rosario, Veldhoen, Renauld, Jarra, Sponaas, Roetynck, Stockinger and Langhorne. This is an open-access article distributed under the terms of the Creative Commons Attribution Non Commercial License, which permits non-commercial use, distribution, and reproduction in other forums, provided the original authors and source are credited. 


\section{APPENDIX}

Table A1 | Primers used for Real-time quantitative PCR reactions.

\begin{tabular}{lll}
\hline & Forward sequence & Reverse sequence \\
\hline Ubiquitin & TGGCTATTAATTATTCGGTCTGCAT & GCAAGTGGCTAGAGTGCAGAGTAA \\
IL-17A & TCCAGAAGGCCCTCAGACTA & CAGGATCTCTTGCTGGATG \\
IL-17F & CTGAGGCCCAGTGCAGACA & GCTGAATGGCGACGGAGTT \\
IL-22 & TCCGAGGAGTCAGTGCTAAA & AGAACTGCTTCCAGGGTGAA \\
IFN-• & GGATGCATTCATGAGTATTG & CTTTTCCGCTTCCTGAGG \\
\hline
\end{tabular}

